\title{
Unilateral action urged
}

\section{London}

THE Energy Committee of the House of Commons this week advocated modest unilateral action to reduce British production of greenhouse gases, in the process deftly turning most of the special pleadings of the energy-producing industries.

The committee's report, Energy Policy Implications of the Greenhouse Effect (HMSO, £8.70), is based on the assumption that international action will follow quickly and on the argument that action should not wait on the removal of uncertainties about the scale of the greenhouse effect.

The committee, noting that its remit is merely to look into matters covered by the government's Department of Energy, has nevertheless taken a broad view, producing a useful summary of the state of research and of the outcome of last year's conference on the subject at Toronto.

While accepting that "draconian" unilateral action could be economically perilous, the committee notes that some kinds of energy efficiency may be economically advantageous. It says that Britain "should consider setting an example to others", repudiates the idea that "because one cannot do much, there is no point in doing anything at all" and quotes Edmund Burke as saying, "nobody made a bigger mistake than he who did nothing because he himself could only do a little".

But what? Taking account of the greater infrared absorbtion by methane and chlorofluorohydrocarbons (CFCs) than by carbon dioxide, the committee argues for the reduction of methane leakage from gas pipelines (400,000 tonnes in 1987), the legal restraint of petrol (gasoline) leakage from automobiles (originally meant to combat smog by reducing tropospheric ozone, which is a greenhouse gas) and continued tightening of nitrogen oxide emissions from automobiles.

Methane from landfill sites, equivalent in its greenhouse effect to 10 per cent of that of carbon dioxide released each year in Britain, could be used economically as fuel or, alternatively, the dry waste from which it derives could be incinerated economically and with benefit.

The committee has uncovered an anomaly in the tarrifs charged by British Gas for supplies to industrial consumers which, it says, encourage inefficiency; it wants that state of affairs remedied.

Of greater potential importance is the proposal that natural gas should be substituted for other fuels (on the grounds that its energy content per unit of carbon is greater than that of coal and oil). The committee dismisses British Coal's objections, but acknowledges that British reserves of natural gas are estimated at only 40 years of supply, and that there may persist economic objections to substantial imports. "Orimulsion" (an emulsion of crude oil in water) is mentioned favourably, as is a Canadian plan to ship 100,000 tonnes of hydrolytic liquid hydrogen to West Germany for use as fuel.

On nuclear power, the committee is agnostic on the view of the Central Electricity Generating Board (CEGB, the largest utility, still nationalized, but not for much longer) that it could commission two pressurized water reactor nuclear power stations a year in the early 2000 s, but says it is unlikely that there will be a programme on such a scale, given public distrust of nuclear power and the impending privatization of the industry. But the committee believes it would be "sensible" not to run down the fast-breeder programme as now intended.

The case of a promising coal gasification plant originally mounted as a joint project between British Coal and CEGB, from which the latter has withdrawn, emerges as a minor scandal. Completion of the project is in limbo for lack of funds, which the Department of Energy has been urging should be found from overseas, but for which it has now promised to seek government support in the next budget.

For the short run, the committee comes down in favour of energy efficiency (but renewable sources of energy get favourable mentions), acknowledging that market mechanisms are probably insufficient to make much difference. On the proposed carbon tax, the committee says that this would be inequitable if not international, but that a European Community tax taking account of all forms of pollution related to energy production might be workable.

The influence of the committee's report is unlikely to be huge. In due course, the British government will have to respond, even though (as some now speculate) the Department of Energy will have ceased to exist by the time it is considered seemly to have done so. The chief significance of the overpriced document is probably that it reflects the eagerness of a group of politicians in a conservative country to be doing (or to be seen to be doing) something.

\section{Grey marks from US group}

\section{London}

US psychiatrists acknowledge that there has been much progress in the improvement of the practise of psychiatry in the Soviet Union, but believe there is still some way to go. This is the gist of a report, issued last week in Washington, by a 26person delegation of US psychiatrists and lawyers visiting the Soviet Union in February to test claims that the abuse of psychiatry to punish political and religious dissent is a thing of the past. Soviet psychiatrists are anxious to confirm their reinstatement as members at the next Congress of the World Psychiatric Association in October.

The delegation, which was led by Bill Farrand of the US State Department and Dr Loren H. Roth, was allowed to nominate the patients it wished to examine. Originally, 48 were named, 37 of them then in hospital. By the time the delegation arrived 17 had been, or were on the point of being, discharged, 4 were not available (due to death, imprisonment, emigration to the United States and insufficient data) and several did not wish to be examined by the delegation.

Only 27 patients, 15 in hospital and 12 discharged, were examined. Of these, the delegation notes, 5 were hospitalized when, by Western standards, they did not warrant a diagnosis of mental illness. Two of these were confined under Article 70 of the Soviet Criminal Code (Anti-Soviet Agitation and Propaganda).
One of the hospitalized patients had been admitted in December 1988 with a diagnosis of schizophrenia, after a long period of activity on behalf of human rights. Although the patient had been discharged in February, he had never had to be charged with crime or diagnosed as sick because he was still on the psychiatric register after an earlier admission.

The delegation notes that mild disorders in several of the discharged patients would have been insufficient to warrant compulsory hospitalization in the West, and that that the diagnosis of "sluggish schizophrenia" in political activists seems still to be commonplace. The delegation has not been able to establish whether past abuses were deliberate, or whether the psychiatric confinement of dissidents had ever been accepted as government policy.

The Soviet reply, also now published, accepts that the US report is a "serious attempt to analyse the current situation in Soviet psychiatry", but repudiates allegations that the US delegation was deliberately impeded in its work. (Bureaucratic bungling was given as the true cause.)

But the Soviet psychiatrists accept US criticism of the use of sulfazine and atropine comas, while denying that these treatments are now used punitively. They also maintain that the US delegation approached the investigation in a onesided manner and had too narrow a view of what constitutes criminal liability.

Vera Rich 